\title{
The Impact of Renewable Energies on Sustainable Development
}

\author{
Foued Sabbagh
}

\begin{abstract}
The people of the world have entered a decade phase after bidding farewell to the previous year 2019 and to begin with stability towards a future that is looming on the horizon of many variables that could shape the characteristics of the next decade with the start year of 2020, it will therefore constitute a fundamental change for the future of daily life and the international economy.
\end{abstract}

Keywords: Renewable energies, sustainable development, green economy, natural electricity, clean technology

\section{INTRODUCTION}

$\mathrm{T}$ oday, the world is witnessing a continuous and growing renewal in various fields and sectors, in particular in the field of the digital economy, which has become a real bet in a direct way on the new technologies of communication and information. In addition, the green economy is considered to be the back home of sustainable development and it is classified among the characteristics of economic modernity of the last decade so that research development and innovation can be doubled at its heart so to achieve a true balance which guarantees the required productivity and national wealth and to maintain a healthy environment without gaseous toxins. The traditional energies that humanity used in the primitive phases of the industrial revolution to operate machines and energies such as cars, planes and trains, in particular petroleum energy and its derivatives such as gas or also nuclear energy, which has all caused a real environmental catastrophe today, which has caused the ozone layer to burst. They have also caused land pollution and the spread of natural disasters such as floods, earthquakes, global warning and climate change. On the other hand, environmentally friendly renewable energies are considered to be a main alternative to these polluted traditional energies.

Manuscript received on 15 October 2021 | Revised Manuscript received on 26 October 2021 | Manuscript Accepted on 15 November 2021 | Manuscript published on 30 November 2021. * Correspondence Author

Foued Sabbagh*, Finance and Development, Faculty of Law and Economics and Politics Sciences/University of Sousse, Erriadh City, Tunisia. Email: fouedsabbagh 2010@yahoo.fr

(C) The Authors. Published by Lattice Science Publication (LSP). This is an open access article under the CC-BY-NC-ND license (http://creativecommons.org/licenses/by-nc-nd/4.0/)
They also have the same operational results as those with less disasters and costs, and among the most important of these energies, we mention in particular that the production of electricity from solar energy and the sales volume and the production of biofuels from vegetable oils such as corn, sunflower and the Jatropha or the use of new clean technologies which are considered a current event which can shape the main features of the future of the technological industry.

\section{THE PRODUCTION OF NATURAL ELECTRICITY}

Nature is considered a main source for the production of energy in large quantities and efficient and effective power. Also, it has become in consumption with the lowest possible costs, so that most countries of the world today reach it as a serious alternative to the production of electricity from fuels and large tanks. Nature has major advantages and contributes to maintaining a clean environment without toxic gas emissions, including mainly wind energy which is available continuously over a long period exceeding six months of the year.

In addition, including solar energy, especially on the African continent, in Latin America and in some Asian countries, so that it forms a major production base with the lowest financial costs. First, by installing panels to produce these types of energies and then the storage and finally the conversions for electrical consumption. In this regard, many European companies, particularly in the southern Mediterranean countries, such as Egypt and Tunisia have already started to distribute and exploit these solar panels to produce natural electricity and then to direct towards the Northern Mediterranean countries, which means that the countries of the European Union will be among the largest consumers of natural electricity.

Thus, also with regard to aerobic turbines to generate electricity from the wind, they also became propagated and visible on most of the hills of the mountain in various countries of the Southern Mediterranean. Overall, this electric power is currently considered the best to reduce the burden of public expenditure on the purchase of fuel, especially in non-oil countries to produce electricity at lower costs.

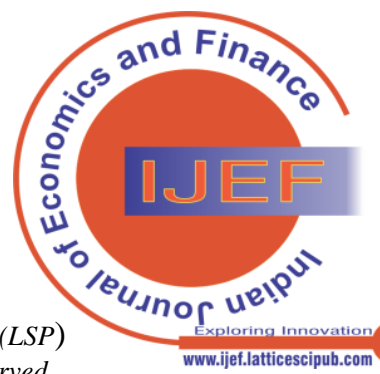




\section{The Impact of Renewable Energies on Sustainable Development}

\section{BIOFUELS - BIODIESEL}

Today, the biofuels extracted from vegetable oil are among the most important types of emerging renewable energy, especially in emerging countries so that they have a direct impact on the consumer and also on public consumption.

We note that the production costs and the prices of its supply which are generally less expensive. This energy, as under the name of biodiesel and it is even capable of operating all industrial engines and machines constantly and continuously, and has almost the same operational capacities as the use of other energies. Among the most important oils extracted from this energy we note in particular corn, sunflower and the most important is the Jatropha plant which is very similar to the natural oils in terms of productivity.

These oils are refined and processed in laboratories to produce large quantities of biofuels called biodiesel or "Green fuels". In addition, most of the stations of the world that supply gasoline to cars have become a major distribution of this type of fuel, especially in developed countries.

\section{THE CLEAN TECHNOLOGY}

The technology has become a tangible reality in our daily lives and this next decade is considered to be technological by excellence due to the increasing prevalence of technologies, research and innovations devoted to the industry, especially in the automotive sector, and household manufacturing which has become largely dependent on electronics and the use of the internet connection in the simplest parts of our lives. The clean technologies are the bet of the future in order to reduce the proportion of toxic gas emissions from the consumption of crude oil and fuels, which have globally become the main cause of major environmental disasters, in particular the problem of pollution nature and air in all cities of the world. It has also now become the main contributor to the stimulation of sustainable development because of its important role in achieving a balance between industry and environment. For example, we mention the TESLA car, which has spread rapidly in recent years to highlight charging stations for this type of car at supply stations, which is very similar in design to cell phone. This technology is also easy to use efficiently and achieves its goals with high quality and equally effective precision.

\section{CONCLUSION}

The renewable energies have become the bet of the future of the world to achieve sustainable development which takes into account productivity in constant and required quantities and also contribute to the development of industry and technology and maintain an environment without of toxic gas. Furthermore, in this regard, the natural electricity extracted from wind and solar energy is considered to have a direct positive impact on the national economies of most countries of the world so that it contributes to reducing the budget deficit, limits the accumulation of debts, increases the economic growth rates and therefore preserves the environment and is capable of achieving the desired sustainable development. The biofuels have recently been the main global event at the heart of the green economy, known as biodiesel extracted from vegetable oils, in particular from the Jatropha plant or also by the recycling of household waste, plant materials and plastics.

\section{AUTHORS PROFILE}

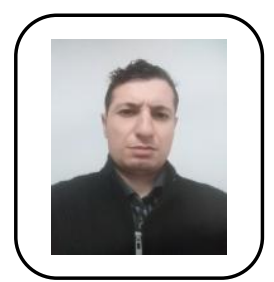

Foued Sabbagh, Masters Degree in economics sciences specialty Finance and Development in 2010 from the Faculty of Law and Economics and Political Sciences of Sousse - University of Sousse Tunisia and International Economic Researcher, fouedsabbagh_2010@yahoo.fr https://www.academia.edu/FouedSabbagh

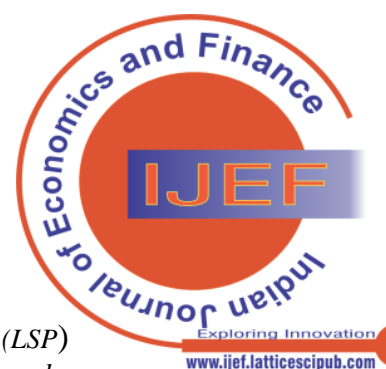

